D. Rodríguez Goyes and N. South (2017) 'Green criminology before 'Green Criminology': amnesia and absences', Critical Criminology, 25, 2:

\title{
GREEN CRIMINOLOGY BEFORE 'GREEN CRIMINOLOGY’: AMNESIA AND ABSENCES
}

David Rodríguez Goyes ${ }^{1}$ and Nigel South ${ }^{2}$

In memory of Lolita Aniyar de Castro (1937-2015)

\begin{abstract}
Although the first published use of the term 'green criminology' seems to have been made by Lynch in 1990, elements of the analysis and critique represented by the term were established well before this date. There is much criminological engagement with, and analysis of, environmental crime and harm that occurred prior to 1990 that deserves acknowledgement. In this article, we try to illuminate some of the antecedents of green criminology. Proceeding in this way allows us to learn from 'absences', i.e. knowledge that existed but has been forgotten. We conclude by referring to green criminology not as an exclusionary label or barrier but as a symbol that guides and inspires the direction of research.
\end{abstract}

Keywords: amnesia; blindness; criminological absences; green criminology; intellectual history; language and translation.

\section{Introduction}

The introduction of a green perspective into criminology-usually claimed to have originated in the 1990s (Lynch, 1990; South, 1998) - has been invigorating, refreshing and, in many respects, has been regarded as a relatively 'new' addition to the field. As the work in this area has developed, however-and with time for reflection-it has become clear that a concern with environmental issues and the abuse of nature can be found in some earlier literature on the sociology of deviance and criminology, social problems and political economy. These pre-date the emergence of a body of work that has explicitly referred to itself as a 'green' (South, 2014;

\footnotetext{
${ }^{1}$ Oslo University and Antonio Nariño University, d.r.goyes@ jus.uio.no,

${ }^{2}$ University of Essex and Queensland University of Technology, soutn@essex.ac.uk
} 
South and White, 2016) or 'conservation' (Gibbs et al, 2010) criminology. Various traces and evidence of these earlier engagements with environmental themes and problems can be found in numerous works (and their bibliographies) that provide early intimations and examples of a 'green criminology'. These were often acknowledged as building blocks which provided a foundation for further work (South, 1998: 214-215). Some, though by no means all, of these were well known in their existing sub-fields and included research and scholarship on: corporate and organised crime that exposed the control and manipulation of waste disposal processes, and the production and distribution of toxic chemicals; the appropriation of animals, birds and fish through 'traditional' legal or illegal activities (e.g., hunting, poaching, illegal fishing) that looked at motives, legislative and regulatory measures and official environmental law enforcement; and environmental inequalities with respect to access to environmental 'goods' and related disproportionate 'bads', such as the siting of industrial power plants and toxic waste sites. Indeed, with respect to the last of these, the concept of environmental justice was a profoundly important foundation. This was grounded in sociological and community-based work on empirical links between toxic environments and disempowered people (the poor, the dispossessed, people of colour), and to campaigns against the discrimination and racism that frequently determine the distribution of environmental advantage and disadvantage. ${ }^{1}$ But these numerous works did not constitute, either by virtue of self-identification or external commentary, a coherent or linked narrative or arc within the criminological story.

This article explores some 'pre-green criminology' statements and arguments for the criminological salience of the environment and ecological systems, focusing, in particular, on sources that may not have featured in the criminological reference lists of the early writers on green criminology. There may be various reasons for such oversight and absences but most usually this will be due to the fact that these other contributions originated from beyond the transatlantic pool of scholarship that has tended to limit horizons. By extension, this means green criminology has not been as informed as it might have been by relevant work in languages other than English and in disciplines other than criminology.

In this article, we try to illuminate the antecedents of green criminologies-before the term 'green criminology' was introduced. While an exhaustive review is not possible, we provide examples of work from Australia, France, Latin America, Slovenia, the UK and the USA, where research on environmental crime and harm was developed—even if only briefly and even 
if not always seen as 'criminological'-in the 1970s, 1980s and 1990s. Proceeding in this way allows us to highlight certain 'absences', i.e., knowledge that existed but has been forgotten or even erased. While we focus on specific countries here, we acknowledge that examples from many others could be offered. Our point is that a considerable amount of knowledge that could be regarded as a contribution to a 'green criminology' has long existed, but has been either forgotten or overlooked. For example, relevant research carried out in the Scandinavian countries (see, e.g., Christophersen and Johansen, 1992) has not been acknowledged at large by green criminology because it was produced in Danish, Norwegian or Swedish. As we explain later, this phenomenon is related both to language barriers and to what Santos (2014) calls 'epistemological blindness'. This is one reason why this article also aims to encourage dialog between those who (literally) speak different languages as well as between different traditions, reflecting knowledge from all global locations. In all of this, of course, is the hope that we can all learn from each other.

The structure of the article is as follows. First, by way of background, we present a characterization of contemporary green criminology in terms of some of its starting points, traits and developments. In the same section, we introduce the idea of 'absences' and 'amnesia' in criminology, as tools that will help us understand why modern green criminology has ignored or appeared unaware of earlier developments. In the methods section, we outline the particular lines of enquiry pursued. The findings section synthesises the main propositions of some of these early publications. In the discussion section, we reflect on how concepts that were developed in antecedents to green criminology have been adopted and expanded by contemporary studies-an analysis that shows, for example, that environmentally destructive dynamics described three decades ago, remain present and active today. We conclude by suggesting that 'green criminology' is not an exclusionary label or barrier, but an umbrella term (Brisman and South, 2013) that can in part be understood as a symbol that guides and inspires the direction of research.

\section{Background-Epistemicide, absences and amnesia in criminology}

In contemporary criminology, it was not until the 1990s that a full project that took the natural environment as its main focus appeared in Europe, the United States and Oceania, under 
the name of 'green criminology'. Before it, and since the appearance of the 'Lombrosian project' (Garland, 2002), criminology had acknowledged the influence of factors both internal and external to the individual but only as a means of comprehending other types of crime, e.g., by applying Darwin's (1859) evolutionary theory (South, 2016). Consequently, as Ystehede (2012) acknowledges, it would be a mistake to 'over-emphasize similarities of themes found ... in the mid-nineteenth century and in the present' because there are obvious and significant differences between 'evolutionary biological discourse' and that concerning speciesism and eco-justice.

The first published use of the term 'green criminology' seems to have been made by Lynch in 1990 (reprinted 2006). In Lynch's use of the term, the objective was to reveal and respond to a "variety of class related injustices that maintain an inequitable distribution of power while destroying human life, generating hunger, uprooting and poisoning the environment of all classes, peoples and animals' (Lynch, 1990/2006, p. 3). Evidently, these local and global problems had attracted the attention of scholars, activists, writers, filmmakers and others prior to the emergence of a 'green perspective' in criminology. Here, we argue, however, that although modern green criminology does not have a narrow definition that delineates what is and what is not green criminology, it does have a set of 'starting points' and traits that can help us to understand both how relevant antecedents of green criminology emerged and perhaps also why they did not develop further or at least have more impact.

\section{Starting points, traits and developments in modern green criminology}

A 'green criminology' did not 'just appear', of course. There are antecedents and precursors (South and White 2014; 2016) and various past studies were concerned with environmentally-related damage, crime and victimisation. A number of these may be seen as purely criminological, others as crossing disciplinary boundaries (South 1998: 214). So when does 'green criminology' start? Is it only 'green criminology' if the authors say so and use the term? Is it 'green criminology' if others declare that it is 'under the umbrella' even if the original authors would not use the term? As we have suggested, one way of approaching these questions is to look at 'starting points' and characteristic traits in the development of 'green thinking' in criminology. Among these, we might identify the following (see South, 2014 for indicative references). 
'New Deviancy' approaches, particularly the concepts of labelling and stigmatization, emphasised the need for sensitivity to the situation of the powerless and marginalised, and it is easy to see how the principles and emphases of this re-orientation in the sociology of deviance and criminology informed thinking about speciesism, the treatment of indigenous peoples and environmental injustice. The subsequent Marxist or critical criminologies directed attention toward the crimes of the powerful and the need to address bias within dominant frameworks of law and the forms of private property rights underpinning numerous examples of damage to the environment.

Feminist criminology had a profound impact by examining the victimisation and marginalisation of women as actors (whether criminals, victims, protestors) and the role of men as responsible for violations of women and of civilized life-an analysis that connects with concerns about the commercialized and militarized abuse and exploitation of the environment and other species (see, e.g., Brisman, South, \& White, 2015; Brisman and South in press). Peacemaking criminology was path-breaking in calling for criminology to see the power of respect, conflict mediation and reconciliation, and this translates into a philosophy that emphasises that we should be respecting and treating the planet differently (see McClanahan \& Brisman, 2015). These various sources of critique were part of a wave of counter-narratives and protests that brought together the personal and the political and, for some, the planet (Zelko, 2006).

\section{Epistemological blindness and criminological amnesia}

Santos (2014) refers to a common phenomenon in science relating to the conscious or unconscious preference to accommodate only that which accords with our existing epistemological and methodological configurations, leaving other possibilities and data ignored. The cause of this common 'epistemological blindness', to use Santos' term, is that the production of science involves 'representation', much like the drawing of a map, involving a method and means to provide a representation of something. This process usually entails selecting a limited amount of phenomena to include in the depictions of reality we make, and consequently disregarding a vast amount of other phenomena. Such representation requires us to determine the relevance of the phenomena which we focus on or disregard. In order to represent something, its origins and traits need to be identified first. How we detect and recognize these will determine 
what we see and what we do not. We use methods to detect phenomena that could be of potential interest but at the same time those methods determine that a vast amount of information is immediately discarded without further consideration. We use theories to determine what among the detected has the characteristics for which we are looking. This all means that we sift reality through theories and methods and what appears at the end is what we 'see'. On the other hand, this process also means that we are 'blind' to everything that has not made it through the 'sifting' process and is therefore absent from our knowledge. Spotting the phenomena to which we have been blind can open the doors to new knowledge acquisition.

Aas (2012: 6) has written of the 'seemingly context-free nature of western social theory and its assumptions about the universality of its knowledge production' and suggested that the conventional criminological 'wall map', as based on the 'almost magnetic drawing power of US developments' and 'the immense production of books, journal articles and conferences dedicated to US realities' would 'probably reveal the centre of gravity' as ' situated in the core western, particularly Anglophone countries'. Aas is, of course, questioning the dominance of certain 'assumptions about geo-political context in criminological theory' and the 'reinforcement of existing asymmetries of knowledge (Aas, 2012: 8). Relatedly, Carrington, Hogg and Sozzo (2015: 15) have called for the acknowledgment of spatial particularities and for the democratisation of epistemologies 'by levelling the power imbalances that privilege knowledges produced in the metropolitan centres of the North'. We pursue the same project here, enquiring about the criminological work hidden in unexplored locations. As Aas points out, the collective imaginary in western criminology tends to 'see' in a particular way, assuming that criminology has flourished only in Anglophone countries. Consequently, efforts to detect criminological literature of relevance are always directed to established literatures and databases that reflect this assumption. Indeed, as Brisman and colleagues (in press) have shown, while most of what is acknowledged as modern green criminology has been produced in English and in Englishspeaking countries, in fact, green criminological research has been conducted in a much wider range of countries. It is a widely shared but incorrect image of the location(s) where green criminological work is assumed to have been produced that has implied this conceptual framework is purely a product of the Anglophone core-west. As explained above, epistemological blindness is inevitably experienced by every scholar due to his/her experience of the specific location(s) of knowledge production. As we demonstrate, however, other, over- 
looked works also reflect the characteristics of green criminology and can be recognized as its antecedents.

\section{Methods}

At the time this article was conceived, we were aware of works that could be regarded as precedents for modern green criminology. In order to identify additional examples, we used an archaeology of science method, following Schiffer's (2013: 7) approach to seeking, gathering and assembling scattered pieces of work in a field, in an effort to try to understand the events and contexts that led to the creation of scientific knowledge. Two main sources led us to distinguish relevant material. First, we contacted a number of authors whose work pre-dated 'green criminology' but who referred to criminological research on environmental issues, however briefly. For example, a key figure in the development of a critical approach in Latin American criminology was approached and became a starting point for 'snowball sampling' through a number of other contacts. In a different case, a scholar who had read an earlier account of the history of a 'green criminology' (South, 2014) contacted us. ${ }^{2}$ With the help of such colleagues we were able to obtain further names of relevant authors and pieces. Second, when studying our initial material, we reviewed the bibliographies included in the material so far gathered (as suggested by the authors we contacted, and that which we found ourselves), and this provided directions toward other sources and works that could be viewed as early examples of green criminology. For this second technique, the use of library resources was essential.

\section{Findings}

Our research shows that before the term 'green criminology' was coined, expressions of interest in environmental issues were not unknown in criminology or related fields of the sociology of deviance and social problems (widespread adoption of the term 'criminology' being relatively recent ${ }^{3}$ ). Below, we provide a review of the interests reflected in some of these earlier works, and provide a brief summary of the main propositions of the authors pertaining to what we have referred to as 'green criminology before green criminology'. All these works stem from the early 1970s to the early 1990s and there are connections and overlaps between them as works of their time and with the contemporary expressions of similar interests in green criminology today. 


\section{Remembering early signposts in the Anglophone world}

American radical sociology of the late 1960s and 1970s was often concerned with protest and the critique of corporate power. This was written by people familiar with the ideas of writers, such as C. Wright Mills, as well as the sociology of deviance and social problems, and presented in ways that can be seen to have fed into the further development of a sociology and criminology concerned with the abuse and crimes of power. While the critique of corporate capital remained prominent in critical criminology, however, the environment was not an issue widely taken up even though a radical environmental sociology did emerge, partly born out of activist environmental protests, expressions of a counterculture movement and intellectual statements of the New Left (Zelko, 2006: 23-28). Key works were Rachel Carson's Silent Spring, Herbert Marcuse's One Dimensional Man and Charles Reich's The Greening of America. This divergence seems strange and one example might serve to show this.

One recent environmental disaster that has attracted considerable green criminological attention has been compared to a similar event that was analysed in familiar terms. The $2010 \mathrm{BP}$ Oil leakage into the Gulf of Mexico has been widely written about in green criminology (e.g. Dybing, 2012), but was also remarked upon by the journal Scientific American as a disaster evoking memories of the 1969 Santa Barbara Offshore Oil Field spill (Greenemeier, 2010)—at the time, 'an unprecedented ecological disaster ... caused by a natural gas-induced offshore rig blowout that caught the oil and gas industry off guard and required a tremendous effort to fix.' As Greenemeier (2010) notes, the origins and unfolding of this event were described by Harvey Molotch (1970), a sociology professor at the University of California, Santa Barbara, in an article which 'would go on to become a founding document in the then-fledgling field of environmental sociology'. Yet, this early essay and the event it described do not appear to have received much attention in green criminology despite the many similarities with analyses of the BP spill. Molotch's paper covered themes now familiar in green criminology: bias in the media, the superficial nature of research commissioned by the industry and provided by academics, public disillusionment with science and technology, the denial of widely available evidence of the dangers of drilling in this location, the damage to land and sea life and to human communities, and the implications in terms of the analysis of power in the USA. The 1969 Santa Barbara oil pollution event became a case-study that enabled Molotch to discuss theory, method and the context of radical movements of the period but it is also notable how a modern green 
criminology shares the ambition to be able to describe and analyse environmental damage and the 'surrounding circumstances' in the hope that this will encourage others to 'view power ... more intellectually, more analytically, more sociologically-more radically-than they did before' (Molotch, 1970: 142). Molotch identifies 'a general sociological response' among, at least part of, the Santa Barbara community, who were aggrieved by injustice: 'The powerful are operating in a manner inconsistent with the normatively sanctioned expectations of an aggrieved population' (Molotch, 1970: 142) and aware of the need for unbiased and technically credible information. In later work (Molotch and Lester, 1975: 235), it was shown how 'federal officials and business' representatives could call on 'greater access to news media than conservationists and local officials' and that it is 'symbolic topics and not topics with implications for distribution of wealth' that 'receive preponderant coverage'.

In the same period of the 1970s, in Australia, Hundloe (1978) noted similar influences as triggers to the alarm bells raising environmental concerns there, mentioning Carson's Silent Spring and Ward's (1966) Spaceship Earth, as well as international media reports of environmental disasters elsewhere. Hundloe then set out to investigate what might now be seen as one of the classic green criminological questions: 'Although governments and politicians make strong claims to being pro-environment and conservation-do they mean it?' In other words, crime may not be permitted but perhaps harm is being allowed? As Hundloe (1978: 133) puts the matter: 'Environmental law as it exists in statutes may not have been broken-but it has not been applied in a manner, or to the extent, that the public, or sections of it, would expect it to have been.' Indeed, Hundloe points out, when laws are inconveniently out of line with existing activities or planned projects then governments simply change them. The 'real question', says Hundloe, is 'whether or not environmental protection statutes are genuinely meant to protect the environment' (1978, pp. 133-134). The author then presents a series of case studies regarding the effectiveness or otherwise of environmental protection law and processes but says he will 'leave it to the reader' to decide the answer to the question posed about the intent underlying laws of protection. This he does and there is little in the essay by way of theory and analysis to provide depth to our understanding of the processes of mystification and denial going on here. This set of case studies, however, does serve as an early Australian contribution to the 'green criminology story', with Hundloe concluding that in 'say, five years time', another researcher 
writing a similar essay might have 'far more interesting tales to tell—and a far more degraded environment in which to live' (p. 160).

In the early 1980s in the UK, various writers followed the lead of New Deviancy theories and then the rise of Marxist criminology to develop analyses of social issues that highlighted the crimes of the powerful, the bias of law and the theft of the rights of others. Auld and colleagues (1984), working on the growth of drugs economies in the 1980s, extended this approach to consider how domestic markets - in this case in illegal drugs-were related to global patterns of exploitation of natural resources and legacies of colonialism. Through these mechanisms, western nations had manipulated and pushed down prices for agricultural cash crops, minerals and other raw materials thereby encouraging the growth of alternative, profitable informal/illicit drug economies. This kind of analysis is also reflected-but with even clearer connections to its environmental implications - in the work of del Olmo (1987) in her powerful examination of 'Aerobiology and the War on Drugs' as a transnational crime and an act of 'eco-bio-genocide', discussed below.

\section{Beyond the Anglophone_Lost through no translation}

As already noted, green criminology has-like most of the field of criminology-tended to reflect a very 'western' character and set of concerns, and has largely communicated these in English. Yet, it is obvious that other 'green' research literatures in other languages must exist and be highly relevant. The problem perhaps has been that in the absence of translations, the western English-language literature does not 'see' or 'hear'; but in addition, there is a failure of intellectual curiosity and willingness to search and learn from 'elsewhere'. ${ }^{4}$

One now well-known example of this situation (publicised by Eman et al, 2009: 584), is the work of the Slovenian criminologist Janez Pecar (1981), who put forward one of the earliest elaborated statements about the need for a new criminological agenda that would examine environmentally-damaging forms of criminality, and the role of criminology and sciences related to this. Pecar observed that 'environmental crime or deviance against the environment is only partially studied' in criminology and the subject neglects 'global issues'. This also anticipated recent work in English that has argued that environmental harm is a product of the actions of major actors, such as corporations and governments as well as the daily consumption behaviours of ordinary individuals. Thus, in discussing the 'aetiology of "environmental" crime', Pecar 
observed that we should 'distinguish between corporate pollution' and other sources of such crime which may be 'perhaps completely private, individual and episodic.' Unfortunately with no English-language translation, Pecar's article made no international impact. ${ }^{5}$

Although Pecar provided the beginning of a criminological agenda, his essay was not the only one of this period to explore conceptually the matter of 'ecological crime'. A review essay by a Swiss lawyer and socio-legal scholar, Jean-Denis André (1980), then affiliated with the University of Geneva, provides another important early statement. This article seems to have been André's only contribution to this area of research (but see also Robert, 1989, for another early, general contribution). In what follows we are, as noted in endnote 2, grateful for, and drawing upon, communications from our French colleague Gregory Salle. It is extremely valuable to be able to draw upon this knowledge of sociology and criminology in France because it presents us with a case of an innovative paper that was not translated-explaining lack of impact in the English language literature-but that, curiously, made very little impact in the French language literature even though published in an important journal. It is possible that the intellectual and political mood was not receptive at the time and, as Salle remarks, this review essay ("synthèse bibliographique", 1980: 400) still remains a 'little-known contribution', with 'the French-speaking literature on this subject' remaining 'very poor since then' ${ }^{6}$.

André provided an early conceptual exploration of environmental questions for criminology and, in the absence of French sources, draws largely upon various German academic references. Importantly for a 'history of green criminology', André's introductory comments make reference to the $17^{\text {th }}$ French Conference of Criminology, which took place in 1977 and was devoted to the theme of "ecological crime" ["délinquance écologique"], the proceedings of which stated that there was, at that time, "no literature and no research on the issue of ecological crime" (Andre, 1980: 399)7.

André's concerns are, first, with the problem of definition, raising conceptual issues about the notion of 'ecological crime' and asserting that no existing definition (the article examines several of them) proves fully convincing. Second, André draws attention to an event the author regarded as a 'landmark' in the construction of the environment as an issue meriting serious academic attention - the First Conference of the French Society for Environmental Law held in 1976 (André, 1980: 402) — with the author arguing not so much that environmental harms 
were totally overlooked before this event but that this was the first time that the idea of considering these harms (or certain types of harms) as 'real' crimes was expressed. The article also makes a distinction between four narratives/explanations/arguments/positions ("parcours argumentatifs", André, 1980: 403) that underpin and account for greater awareness of the concept of 'ecological crime'.

On the one hand, ecological 'crime' can be seen as resulting from harmful activities or attitudes that now come to be judged by society as not only damaging or dangerous but criminal, even if social awareness remains limited and judicial sanctions weak or lenient. The crucial turning point is less a matter of shifting public perceptions than the outcome of a change of attitude within the criminal justice system, as a response to a general demand for greater protection. As such, it is argued that the criminal law should now begin to incorporate relevant norms and expectations and not simply rely on special administrative laws. This shift is a necessary condition for the acceptance and perception of these 'offences' as equal in seriousness to more familiar, 'ordinary', crimes. On the other hand, a slightly different and more 'critical' view articulated by André, argues that ecological crime is so different and specific compared to other criminality that it requires special legislation in response.

André's article concludes with an anticipation of a classic challenge in critical criminology - the paradox of calling for criminalisation and control of behaviours (in this case those damaging to the environment) where in other contexts and as a general principle, 'decriminalisation' and the curtailment of control is favoured. André refers to new Marxist influenced developments in criminology and notes that the issue of environmental crime is a mirror of an ecological crisis, which in turn reflects - and is an outcome of - the workings of the global social system. (Had his argument been more widely known, perhaps, this promising set of connections could have been built upon by others.) Ultimately, says André, the absence of formal and consistent socio-political and legal priorities regarding the environment may explain why the emergence of the concept of ecological crime remained—at the time-one without real substance.

The cusp of the 1980s was also significant in Spain following the 1978 Constitution which opened up the possibility of renewal of all laws in the country. In response, Rodríguez Ramos (1981) published an inquiry into the role of the Spanish legal system regarding 
environmental protection. For this study, Rodríguez relied on what he then referred to as a 'Criminología del Medio Ambiente' (criminology of the environment). His preliminary assessment showed that, at that time, there was no direct protection of the environment offered by the criminal law system-only an indirect and anthropocentric defence (examples would include the criminalization of behaviours such as spillage of toxic substances, arson, hunting on private property, contaminating water and food). Rodríguez argued that the environment is seen by the law as protected by a right, which meant humans should be able to enjoy it. This was matched by the duty of humans not to disturb the right of other humans to such enjoyment. Rodríguez did not criticise the anthropocentric orientation of this legal position but did assert that because the effective protection of the environment depends on social arrangements, the creation and application of environmental criminal law should be based on criminological findings. Thus, he rejected the legalist ideology which assumed that the mere criminalization of behaviour directly and effectively protects the environment. Based on his research, he argued that the perpetrators of environmental crimes could fall into three categories: (1) perpetrators by ignorance; (2) indirect perpetrators (who harm the environment as a non-sought-after consequence of another harmful act); and (3) financial or industrial perpetrators. Given that in his view, the economy-ecology tension was the main producer of environmental degradation, the main focus of response should be on the third type. Sub-categories of these 'financial and industrial perpetrators' are (i) those excessively greedy for profit; (ii) those too attached to property; and (iii) those with an interest in continuously expanding growth and increasing commodity production. With all this in mind, and in order to ensure that adequate strategies are used in an adequate way, Rodríguez made a call for more studies in the criminology of the environment and more research on environmental offences, before using the criminal law to address environmental issues.

\section{Learning from absences: Environment, crime and power in Latin America-a rich but overlooked criminological history}

When talking about counter-colonial criminology, Agozino (2003, 2004) asserted that criminology is almost non-existent in former colonies either because: being an imperialist endeavour, it is assumed in these locations to be of no value and consequently ignored; or, because when endogenous criminologies developed in those countries, they were suppressed by those in power who feared scrutiny, critique and exposure. Agozino's thesis is true to a certain 
degree when applied to the Latin American case, where a proper 'Latin American criminology' (as opposed to the criminology imposed on Latin America) began with the 1974 criminology congress in Maracaibo, Venezuela. After carrying out important research on white-collar criminality, many of the participants in this intellectual movement were killed or exiled under the dictatorships, and as a consequence, a significant proportion of criminological knowledge was lost. Some well known victims of this 'epistemicide', to use Santos' (2014) term, were Juan Bustos Ramirez, imprisoned in 1975 during the Chilean dictatorship of Pinochet; Jorge Enrique Torres, killed in 1977, and Guillermo Monzón and Jorge Palacios, killed in 1981—all three under the dictatorship of Efrain Rios Monte in Guatemala; Alfonso Reyes Echandia, murdered in 1985, in Colombia; and Roberto Bergalli, exiled under the dictatorship of Videla in Argentina (Aniyar de Castro, 1987).

Agozino's hypotheses, however, do not necessarily apply in the case of the criminological study of environmental issues developed in Latin America since the 1970s. Most of the authors that called for a criminology concerned with the environment lived long lives and most of them remained in academia their whole careers. Their proposals for the elaboration of such a criminological approach, however, were not developed further by themselves or by others, and what could have been a long-standing green criminology now consists only of dispersed writings in difficult to find books.

The shortcomings of Agozino's thesis can be illustrated by reference to the ideas of Benavides (2008), who asserted that criminology in Latin America disappeared for a long period because criminology ceased to be influential in the political realm as its role was taken by technical disciplines. This happened during the 1980s with the arrival of "development" projects led by the World Bank, the International Monetary Fund, United States Agency for International Development (USAID) and other institutions of global governance. Sociological studies were no longer sought; instead, technical reports to pave the road for progress were in demand. Consequently, criminologists—most of whom were lawyers by training-returned to the practice of law and their place was taken by economists. This historical shift is significant in highlighting one of the risks green criminology may face: exclusion from scenarios of influence due to inability or unwillingness to engage with contemporary dynamics of power and decision making. This is a familiar dilemma for critical criminologies more generally and reflected in discussions of a 'public criminology' (Hughes, 2017). 
In 1992, Peruvian criminologist Pierre Foy Valencia, set out a comprehensive-yet succinct-program for criminological research on environmental issues, which he called ‘criminología ciencias ambientales' (environmental sciences criminology). He also defined criminalidad ambiental o violencia ambiental (environmental criminality or environmental violence) as the transgressive behaviours that negatively affect the environment, and the life quality of current inhabitants and future generations: 'It is necessary from the fields of the legalpenal and environmental sciences, as well as from modern criminology to contribute to the creation of a consistent theory and model for the systemic analysis of environmental criminality' (Foy Valencia, 1992: 268-269). Aware that the study of environmental issues exceeded the capacities of then-contemporary criminology and required an integrated framework, he formulated a series of considerations aimed at reframing criminology to make it an ecologicallyinformed discipline able to deal with green issues. The principles of this program were as follows: First, the development of a transdisciplinary study where knowledge from anthropology, ecology, political science, and social psychology were combined with that pertaining to criminology. Second, paying attention to the diverse geographical locations and levels (local to global) where environmental problems are generated and experienced: 'without a doubt this ...requires an integration of national phenomena, with those of international character [...] regional character, and global character' (Foy Valencia, 1992, p. 258). Third, the use of a sociological approach that could help reveal the organizational configuration of the agents directly involved in environmental degradation, and its prevention, and fourth, the development of an environmental victimology. The urgency of implementing this program, argued Foy Valencia, was due to the lack of this type of research in Peru, resulting in a permissive penal law that was allowing an environmental crisis caused by the actions of white collar, corporate or economic crime. Consequently, the findings of a criminología ciencias ambientales should ideally inform a Peruvian process of initiating the criminalization of environmentally transgressive behaviours.

\section{The development of the critical tradition in Latin America: research on white collar crime}

Edwin Sutherland's While Collar Crime (1961) played an important role in the development of Latin American criminology's interest in environmental issues. In 1969, Venezuelan criminologist Rosa del Olmo translated the text under the title Delito de Cuello Blanco (Sutherland, 1969). The ideas it contained led a group of Latin American scholars to initiate a project in 1977 on "White Collar Crime in Latin America". The goal was to "understand the 
relationship between political power and economic power in Latin America, and how this determined .... [a]n institutional and legislative structure that extracts the crimes of the powerful from the penal and penitentiary spheres [... and also examine] [t]he purely symbolic nature of the law, evidenced in the important sub-projects on environmental crime (Mexico, Panama, Venezuela)' (Aniyar de Castro, 1987, p. 12). Seminars on the topic were held in Rio de Janeiro, Brazil (1979), Valencia, Venezuela (1980) and México (1981). Products of this project are works like 'A design for research on environmental crime' (Burgos Finol, n.d.); 'White collar crime as ecological crime' (Arreaza de Márquez \& Burgos Finol, 1981); 'Penal law and Environmental Crime (Martinez Rincones, 1993), among others. ${ }^{8}$

Representative of this research was del Olmo's (1987; see also 1998) analysis of the war on drugs pursued by the United States against marihuana and coca production in Latin America. According to del Olmo, the driver of drug production in the 1980s in Latin America was demand from the United States, and the way the United States responded to drug 'problems'. The United States decided to confront the 'drug problem' not by addressing internal demand, but by targeting its production in other countries. Consequently, the focus was on interdiction (confiscation at borders) and eradication, which was implemented by means of a complex of toxic chemicals such as Paraquat and Gliphosate (also known as Round-Up, produced by Monsanto). Fumigations were indiscriminate and also affected food crops, thus bringing about a food crisis. By that time, it had already been proven that Paraquat causes lung damage and that both Paraquat and Gliphosate are lethal for fauna and sea life. Building on these insights, her analysis of the War on Drugs was focused not on the crimes involved in drug production and trafficking, but on the harms caused by the war. The main harm of concern was that of 'ecocide, against the destruction of the environment, and more concretely biocide, if we bear in mind the future' (del Olmo, 1987, p. 30). del Olmo presented the War on Drugs as a 'crime' that had been justified by the United States as a means of preventing drug crimes but in the course of pursuing this war, its militarised police actions widely damaged the environment and thus the living conditions of local populations. del Olmo characterized this as the transnational crime (because the crime was planned in one country and then carried out in others) of 'eco-bio-genocide'-a type of criminality against the environment, where the governments of Latin America and its peoples were the victims. According to del Olmo, this crime was facilitated by the lack of environmental laws in Latin American countries, and given momentum by the double standards 
of the United States, where the use of these chemicals was strictly controlled due to their toxicity, while at the same time, the United States encouraged their extensive use in countries such as Argentina, Bolivia, Brazil, Colombia, Ecuador, Mexico, and Peru. While del Olmo continued studying the environmental harms produced by the war on drugs, she did not fully explore this vein of work, as she was engaged with other serious issues that have historically affected Latin America, such as prostitution and other forms of violence against women. Nevertheless, del Olmo called for criminological communication to be 'established on a reciprocal basis' where ‘superior-inferior relationships do not predominate' (Encinoza \& del Olmo, 1981, p.67)—a call we echo thirty-five years later.

\section{Discussion-Forgotten and recurrent concepts}

In our analysis of green criminology precedents, we found several examples of earlier articulation of concepts currently used and developed by modern green criminology. For example, two main highlights of Rodríguez Ramos' work are: the conceptualization of environmental law as an anthropocentric tool—something that has been further developed by Sollund (e.g. 2011); and the identification of the production system as the main source of environmental harm, which has been extensively studied by Stretesky and colleagues (e.g., 2014). del Olmo used a harm perspective when studying a phenomenon that was not criminalized, something frequently adopted in green criminology (e.g. Halsey \& White, 1998; South, 2007). del Olmo also identified the transnational framework in which most green harms are producedone that is now exposed as a fundamental methodological principle when designing green criminological research (e.g. White, 2012) — and she accentuated the inequitable distribution of environmental 'goods' and 'bads', echoed in subsequent green criminology (Davis, 2014; Lynch, 1990/2006; Schlosberg, 2007). Finally, she integrated into her analysis the concepts of ecocide, biocide and ecological genocide, that are now broadly accepted in this field of research (e.g. Higgins et al, 2013; Larsen, 2012) .

Pecar identified two, now major, goals for green criminological research: the importance of identifying environmental crime as caused by actors such as corporations and governments (see e.g. Walters, 2006), and the significance of calling attention to environmental degradation caused by the daily consumption behaviors of ordinary individuals (see, e.g., O'Brien, 2008; 
Agnew, 2013; Brisman and South, 2014). André asked a crucial question for green criminology that has received contemporary acknowledgement but perhaps still not been satisfactorily answered (White, 2012): how should we define 'ecological crime'? This question leads to further and more profound enquiries regarding how to define 'environment' and 'nature' ${ }^{9}$ — questions that undergird much green criminological scholarship but which remain open for green criminology to actively address.

Molotch discussed denial and science discourses as facilitators of environmental harm (see Brisman and South, 2014, Sollund, 2008, and Wyatt and Brisman, 2016, for current debates on the former; Goyes, 2016 for the latter). Hundloe posited questions about the real role of environmental law, questioning whether environmental law genuinely seeks to protect the environment or rather facilitate its exploitation (see Goyes and Sollund, 2016, for contemporary examples of this debate).

If the propositions of the Treadmill of Crime (Stretesky et al, 2014) are correct-and we have enough evidence to argue that they are-practices conducive to environmental harm are more widespread and more intense today than when these antecedents of green criminology were written. The current dominance and influence of neo-liberal economics and policies of deregulation contribute to the acceleration of activities damaging to the environment. Certainly, the similarities between current green criminology and 'green criminology before green criminology' suggest that in spite of earlier expressions of concern, the logics behind environmental harms have not been transformed. This realization should be a call for green criminologists to consider ways to make more effective impacts in environmental harm prevention. Furthermore, we suggest that the evident relevance for present green criminology of the antecedents studied here, should inspire us to further explore the past, as well as to look for 'parallel green criminologies', in order to find other accounts of environmentally harmful practices and dynamics.

\section{Conclusion}

As Foster and Holleman (2012: 1626) have remarked, 'the dominant post-Second World War sociological tradition was seen as having embraced a human-exemptionalist paradigm, in which human beings in technologically advanced societies were considered exempt from naturalenvironmental influences.' The 'dominance' of this tradition was also exercised through being 
largely U.S.-led and carried out in the English language. This does not mean that sociology, political economy or criminology were wholly unreflective or uncritical on such matters-at least from the late 1960s onward-and subsequent work has been able to refer back to the writings of classic analysts of production and consumption in modern societies (e.g., Marx, Veblen, Weber). Nonetheless, environmental issues struggled to find a place of significance on the criminological agenda until the 1990s, despite pioneering analyses of various case studies, explorations of definitions and conceptual questions, a body of contributions from across Latin America and (possibly) the first professional meeting on the subject being held in France in 1977.

We are aware that our archaeological dig has been representative, rather than exhaustive, and has probably failed to uncover many other early examples of a 'green criminology'. This is due to language barriers, unfamiliarity with criminological traditions in continents like Asia and Africa, and the limitations of research conducted through electronic databases. Nonetheless, we believe we have been able to add something to an intellectual history of engagement with one of the most important issues of our time. Appropriately this has also emphasised that environmental challenges are both local and global and that 'criminological thinking' on these matters has also been both local and global. This exercise and discussion is not concerned with the question of 'who was first?' to articulate such concerns, although in a field that celebrates exchange of ideas and giving voice to those whose contributions may have been overlooked or forgotten, it is important to do what we can to address our amnesia, and our willingness to accept intellectual absences. But this article is also a reminder not to make too much of the label 'green criminology'. The term or concept is useful but it is only a signal, symbol, or expression regarding a perspective or orientation toward certain central concerns. It might well be called something else. What is important is the subject matter and as this essay has started to show, the foundations on which scholarship and action might continue to be built are stronger and more international than we might have remembered or imagined.

\footnotetext{
${ }^{1}$ For references and further examples, see, e.g., South (1998: 214-215; 2014) as well as various papers-and their bibliographies_-reprinted in South and Beirne (2006) and White (2009).
} 
${ }^{2}$ We are enormously grateful to Professor Gregory Salle, of the French National Center for Scientific Research (CNRS), University of Lille, for pointing us in the direction of the essay by J-D Andre and the reference to the $17^{\text {th }}$ French Conference of Criminology which took place in 1977 on the subject of "ecological crime" ["délinquance écologique"].

${ }^{3}$ And in some cases still not accepted, see Mucchielli (2014).

${ }^{4}$ It might be pointed out that ability to speak more than one language would help but this takes us into yet another set of issues related to north / south relations, media dominance, foreign policy assumptions, neo-colonialism, and short-sighted educational systems.

${ }^{5}$ Academics writing as a non-English native may find themselves having to publish in two languages - their own and in (possibly more poorly expressed) English. This is a form of academic injustice with implications for the exchange of knowledge.

${ }^{6}$ Note, however, the 2016 special issue of Revue Criminologie on 'Criminalité environnementale' 49,2 .

7 A copy of the Proceedings can be found at: http://data.decalog.net/enap1/liens/fonds/FONDS_PINATEL_09.PDF (retrieved 14th August 2016).

${ }^{8}$ In personal communications, Lolita Aniyar and Emperatriz Arreaza, mentioned a broad range of literature produced on the topic by these and other authors like Carlos Sulbarán. Apart from these works, however, we were not able to locate these documents.

${ }^{9}$ For an indicative discussion on this issue, see the synthesis of the Research Project "European Union Action to Fight Environmental Crime" (EFFACE), page 11. Available at http://efface.eu/sites/default/files/publications/EFFACE_synthesis-report_final_online.pdf. 


\section{References}

Aas, K. F. (2012). 'The Earth is one but the world is not': Criminological theory and its geopolitical divisions. Theoretical Criminology, 16(1), 5-20.

Agnew, R. (2013). The ordinary acts that contribute to ecocide: A criminological analysis. Routledge International Handbook of Green Criminology. N. South and A. Brisman. New York, Routledge: 58-72.

Agozino, B. (2003). Counter-Colonial Criminology. A Critique of Imperialist Reason. London: Pluto Press.

Agozino, B. (2004). Imperialism, crime and criminology: Towards the decolonisation of criminology. Crime, Law \& Social Change, 41, 343-358.

André Jean-Denis, 1980, «Délinquance écologique : de l'artificiel au transactionnel », Déviance et société, 4 (4), pp. 399-412.

Aniyar de Castro, L. (1987). Criminología de la liberación. Maracaibo: Editorial de la Universidad de Zulia.

Arreaza de Márquez, E., \& Burgos Finol, F. (1981). Delito Ecológico como delito de Cuello Blanco. Revista Capítulo Criminológico.

Auld, J, Dorn, N and South, N (1984) 'Heroin now: 'Bringing it all back home", Youth and Policy, 9, 2 : $1-7$

Benavides Vanegas, F. S. (2008). A global zero tolerance? Colombian prisions from a world historical perspective. Pensamiento Jurídico(23), 173-202.

Brisman, A., Goyes, D., Mol, H., \& South, N. (In press). The Theft of Nature and Poisoning of the Land in Latin America. In D. Goyes, H. Mol, A. Brisman, \& N. South (Eds.), Environmental Crime in Latin America: The Theft of Nature and the Poisoning of the Land. London: Palgrave.

Brisman, A., \& South, N. (2013). Introduction: Horizons, issues and relationships in green criminology. In N. South \& A. Brisman (Eds.), Routledge International Handbook of Green Criminology (pp. 1-24). New York: Routledge.

Brisman, A., \& South, N. (2014). Green Cultural Criminology, Constructions of environmental harm, consumerism, and resistance to ecocide. 
Brisman, A. and N. South (2015). State-Corporate Environmental Harms and Paradoxical Interventions: Thoughts in Honour of Stanley Cohen. Green Harms and Crimes. Critical Criminology in a Changing World. R. Sollund. Hampshire, Palgrave macmillan: 27-42.

Brisman, A., and N. South. (In Press) Money, conflict and environmental harm: Illegal exploitation and unethical financial behaviour. In Toine Spapens, Rob White, Wim Huisman and Daan van Uhm, eds. Environmental Crime and the Money. London and New York: Routledge.

Brisman, A., South, N., \& White, R. (Eds.). (2015). Environmental Crime and Social Conflict. Surrey: Ashgate.

Burgos Finol, F. (n.y.). Diseño de investigación sobre delito ecológico.

Carrington, K., Hogg, R., \& Sozzo, M. (2015). Southern Criminology. British Journal of Criminology. doi:10.1093/bjc/azv083

Christophersen, J. G., \& Johansen, P. O. (1992). Forurensing som tradisjon. In P. O. Johansen (Ed.), Studier i Økonomisk Kriminalitet (pp. 254-291). Oslo: Institutt for Kriminologi.

Darwin, C. (1859). On the origin of species by means of natural selection, or, The preservation of favoured races in the struggle for life. London: John Murray.

Davis, P. A. (2014). Green crime and victimization: Tensions between social and environmental justice. Theoretical Criminology, 18(3), 300-316.

del Olmo, R. (1987). Aerobiology and the War on Drugs: A Transnational Crime. Crime and Social Justice, 30, 28-44.

del Olmo, R. (1998). "The ecological impact of illicit drug cultivation and crop eradication programs in Latin America." Theoretical Criminology 2(2): 269-278.

Dybing, S. S. (2012). Environmental Harm: Social Causes and Shifting Legislative Dynamics. Ecoglobal Crimes, Contemporary Problems and Future Challenges. R. Ellefsen, R. Sollund and G. Larsen. Surrey, Ashgate Publishing Limited: 273-294.

Encinoza, A. R., \& del Olmo, R. (1981). The view from Latin America against transnational criminology: A call for democratic international cooperation. Crime and Social Justice, 15, 6167. 
Foy Valencia, P. (1992). Aproximación al estudio de la criminalidad y el derecho penal ambiental peruano. Derecho PUCP, 46, 257-274.

Garland, D. (2002). Of crimes and Criminals, The development of criminology in Great Britain. In M. Maguire, R. Morgan, \& R. Reiner (Eds.), The Oxford Handbook of Criminology (pp. 17-68). Oxford: The Clarendon Press.

Gibbs, C., et al. (2010). "Introducing conservation criminology: Towards interdisciplinary scholariship on environmental crimes and risks." British Journal of Criminology 50(1): 124-144.

Goyes, D. (2016). "Green Activist Criminology and the Epistemologies of the South." Critical Criminology 24(4): 1-16.

Goyes, D., \& Sollund, R. (2016). Contesting and Contextualising Cites: Wildlife trafficking in Colombia and Brazil. International Journal for Crime, Justice and Social Democracy, 5(4).

Greenemeier, L (2010) Gulf Spillover: Will BP's Deepwater Disaster Change the Oil Industry? Scientific American June 7; http://www.scientificamerican.com/article/molotch-deepwaterenvironmental-sociology/

Halsey, M., \& White, R. (1998). Crime, Ecophilosophy and Environmental Harm. Theoretical Criminology, 2(3), 345-371. doi:10.1177/136248069800200300

Huges, G. (2017). Public Criminology. The Routledge Companion on Criminological Theory and Concepts. A. Brisman, E. Carrabine and N. South. Abingdon, Routledge.

Hundloe, T (1978) 'Heads they win, tails we lose: environment and the law', in P. Wilson and J. Braithwaite (eds) Two Faces of Deviance: Crimes of the Powerless and Powerful, St Lucia: University of Queensland Press.

Larsen, G. (2012). The Most Serious Crime: Eco-genocide, Concepts and Perspectives in Eco-global Criminology. In R. Ellefsen, R. Sollund, \& G. Larsen (Eds.), Eco-global Crimes, Contemporary Problems and Future Challenges (pp. 33-56). Surrey: Ashgate Publishing Limited.

Lynch, M. J. (1990/ 2006). The Greening of Criminology: A perspective for the 1990s. Reprinted in P. Beirne \& N. South (Eds.), Green Criminology. Hampshire, UK: Aldershot.

Martinez Rincones, J. F. (1993). Ley Penal y Delito Ecológico. Mérida: Editorial Alfa C.A. . 
McClanahan, B. \& Brisman, A. (2015) 'Climate Change and Peacemaking Criminology: Ecophilosophy, Peace and Security in the "War on Climate Change" Critical Criminology, 23, 4

Molotch, H. (1970), Oil in Santa Barbara and Power in America. Sociological Inquiry, 40: 131-144. doi: 10.1111/j.1475-682X.1970.tb00990.x

Molotch, H and Lester, M (1975) Accidental News: The Great Oil Spill as Local Occurrence and National Event. American Journal of Sociology 81, 2: 235-260

Mucchielli, L (2014) Criminologie et lobby sécuritaire. Une controverse française, Paris, La Dispute

O'Brien, M. (2008). Criminal Degradations of Consumer Culture. Global Harms. Ecological Crime and Speciecism. R. Sollund. New York, Nova Science Publishers, Inc.: 35-50.

Robert, Christian-Nils (1989) 'Protection de l'environnement - Comportements et incidences des normes du droit pénal' in Robert, Christian-Nils Limites du droit pénal : quelques interrogations. Genève : CETEL, 1989.

Rodríguez , L. (1981). Presente y futuro de la protección penal del medio ambiente en España. In CEOTMA/MOPU (Ed.), Derecho y Medio Ambiente (pp. 283-316). Madrid: CEOTMA/MOPU.

Santos, B. d. S. (2014). Epistemologies of the South: justice against epistemicide. Boulder: Paradigm Publishers.

Schiffer, M. B. (2013). The Archaeology of Science. Studying the Creation of Useful Knowledge. Tuscson: Springer.

Schlosberg, D. (2007). Defining Environmental Justice. Theories, Movements, and Nature. New York: Oxford University Press.

Schlosberg, D. (2007). Defining Environmental Justice. Theories, Movements, and Nature. New York: Oxford University Press.

Sollund, R. (2008). Causes for Speciesism: Difference, Distance and Denial. In R. Sollund (Ed.), Global Harms: Ecological Crime and Speciesism (pp. 109-131). New York: Nova Science Publishers, Inc.

Sollund, R. (2011). Expressions of speciesism: the effcts of keeping companion animals on animal abuse, animal trafficking and species decline. Crime Law and Social Change(55), 437-451. doi:10.1007/s10611-011-9296-3 
South, N (1998) 'A green field for criminology?: a proposal for a perspective' Theoretical Criminology, 2, 2: 211-234

South, N. (2007). Nature, difference and rejection of harm: Expanding the agenda for green criminology. In R. Sollund (Ed.), Global Harms. Ecological crime and speciesism. New York: Nova Science publishers.

South, N (2014) 'Green Criminology: reflections, connections, horizons' in T. Wyatt, N. South and P Beirne (eds) (2014) Green Criminology Matters, special issue of International Journal for Crime, Justice and Social Democracy, 3, 2, 6-21.

South, N (2016) 'Monstrous nature: a meeting of gothic, green and cultural criminologies' in M. Brown and E. Carrabine (eds) The Routledge Handbook of Visual Criminology, Abingdon: Routledge

South, N and White, R (2014) 'The Antecedents and Emergence of a 'Green' Criminology', at R. Agnew (ed), 2013 Annual Meeting Presidential Papers: Selected Papers from the Presidential Panels 2013 ASC Annual Meeting - Atlanta Expanding the Core: Neglected Crimes, Groups, Causes and Policy Approaches, ASC website: https://asc41.com/Annual_Meeting/2013/Presidential\%20Papers/2013_Presidential_Papers.html

South, N and White, R (2016) 'L'émergence et l'avenir de criminologie verte' ('The Emergence and Futures of Green Criminology') Revue Criminologie, 49, 2

Stretesky, P. B., Long, M. A., \& Lynch, M. J. (2014). The Treadmill of Crime: Political Economy and Green Criminology New York: Routledge.

Sutherland, E. (1969). El Delito de Cuello Blanco. Caracas: Ediciones de la Biblioteca U.C.V. .

Sutherland, E. H. (1961). White collar crime. New York: Holt, Reinehart and Winston.Walters, R. (2006). Crime, Bio-Agriculture and the Exploitation of Hunger. British Journal of Criminology, $46(1), 26-45$.

White, R., Ed. (2009). Environmental Crime. A reader. Devon, Willian Publishing.

White, R. (2012). The foundations of Eco-global Criminology. In R. Ellefsen, R. Sollund, \& G. Larsen (Eds.), Eco-global Crimes, Contemporary Problems and Future Challenges (pp. 15-31). Surrey: Ashgate Publishing Limited. 
Ystehede, J. (2012). Constructing a Meta-history of Eco-global Criminology: On Brute Criminologists, Mortified Bunnies, Nature and its Discontent. In R. Ellefsen, R. Sollund, \& G. Larsen (Eds.), Eco-global Crimes, Contemporary Problems and Future Challenges (pp. 57-67). Surrey: Ashgate Publishing Limited.

Zelko, F (2006) Challenging modernity: the origins of postwar environmental protest in the United States. In C. Mauch, N. Stoltzfus and D. Weiner (eds) Shades of Green: Environmental Activism Around the Globe, Lanham: Rowman and Littlefield. 